\title{
Hatha Yoga Effect on Airway Resistances of Tobacco Smokers with Allergic Rhinitis
}

\author{
Soumya $\mathrm{MS}^{1}$, Chellaa $\mathrm{R}^{2 *}$ and Inbaraj $\mathrm{G}^{2}$ \\ ${ }^{1}$ Department of Otorhinolaryngology, St John's National Academy of Health Sciences, India \\ ${ }^{2}$ St John's Research Institute, St John's National Academy of Health Sciences, India
}

Submission: June 30, 2017; Published: August 23, 2017

*Corresponding author: Chellaa R, St John's Research Institute, St John's National Academy of Health Sciences, Germany, Tel: +491629-659-513; Email: chellaar@gmail.com

\begin{abstract}
Background: There have been limited studies on Hatha yoga training as a complementary therapy to manage the symptoms of Allergic Rhinitis and also to check the effect of yoga on airway resistances in tobacco smokers with Allergic Rhinitis.

Aim: The main Aim of the study was to check the effect of Hatha yogasanas on the Airway resistances in tobacco smokers with allergic rhinitis.

Materials and Methods: This is a prospective non blinded study of 20Tobacco smokers with allergic rhinitis. In the age group of (18-30). The subjects chosen for the study underwent an ENT examination and Hatha yoga training was giving for a period of 90 days. The objective analysis for upper airway resistance and lower airway resistance was done using a Rhino manometer and Spiro meter. The subjective analysis was done using a SF-12 Health survey questionnaire and a SNOT questionnaire. Both the objective and subjective analysis was done before and after the practice of Yogasanas. The compiled data was analyzed with the paired (2-tailed) T-Test, using SPSS (Software package for social sciences) version 16.
\end{abstract}

Results: The total nasal airway resistance was found to be increased before doing yoga and it was significantly reduced at 150 Pa pressure after doing yoga. The mean FEV1/FVC\% before doing yoga was less when compared with the post yoga measurement. The mean Physical component score (PCS) and Mental component score (MCS) of the SF-12 health survey questionnaire had significantly improved and the mean SNOT questionnaire score had significantly reduced after the practice of yoga.

Keywords: Hatha yoga; Tobacco smokers; Allergic rhinitis; Rhino manometer; Spiro meter; SF-12 Health survey questionnaire; Snot questionnaire Abbreviations: AR: Allergic Rhinitis; SF-12: Short Form 12 Health Survey Questionnaire; SNOT: Sino Nasal Outcome Test Questionnaire

\section{Opinion}

Allergic Rhinitis (AR) is the most common allergic disease, affecting $30 \%$ of population around the world. The disease is predominantly associated with exposure to some aeroallergens like cigarette smoking [1]. Allergic Rhinitis (AR) is usually defined as the presence of at least one or more of the symptoms of congestion, rhino rhea, sneezing, nasal itching, and nasal obstruc $\neg$ tion [2,3]. The disease is an Immunoglobulin E (IgE) mediาated reaction of Th2-type $\mathrm{T}$ cell response [4,5]. Due to the chronicity of disease and the variable response to therapy, a large number of patients resort to complimentary and alternate medication for Allergic rhinitis. Nasal breathing exercise is a simple and cost effective measure to reduce symptoms of Allergic Rhinitis and improve patient satisfaction [6].
Yoga is an alternative to traditional (Western) aerobic exercise that may have promise as a complementary treatment for smoking cessation. Yoga contains a number of components that contribute to stress reduction including asanas, yoga postures that have been shown to improve mood and well-being similar to the effects of traditional Western exercise, [7-10] and pranayama, breathing exercises that involve regulation of breath and conscious deep breathing that stimulates pulmonary stretch receptors similar to the deep in halation associated with smoking [11]. While yoga is associated with health benefits similar to exercise, the goal of yoga practice is also to create a calm state of mind through the combination of physical postures, breathing techniques, and directed meditative focus $[12,13]$. 
Several studies have shown that the practice of yoga reduces perceived stress and negative effect. Thus, the practice of yoga may also improve the chances of successful smoking cessation [14-17].

Yoga training can readjust the autonomic imbalance, controls the rate of breathing, and thus alters various physiological variables. These changes are attributed to the decreased sympathetic reactivity and relaxation of voluntary Inspiratory and expiratory muscles $[18,19]$. The proportion of adolescents with symptoms of asthma or allergic rhinitis who reported smoking experimentation is a cause for concern, because there is strong evidence that active smoking is a risk factor for the occurrence and increased severity of allergic diseases [20]. Passive and active smokings are both risk factors for asthma and allergic rhinitis in adolescents [21-23]. Cost effective options and alternative therapy such as yoga will serve as a solution to manage Allergic rhinitis. The ancient science of yoga includes physical postures, voluntarily regulated breathing, and meditation, among other techniques [24]. Practicing yoga can bring positive effects on well-being and human health with respect to biological and physiological parameters [25]. Voluntarily regulated yoga breathing techniques have been found to increase the oxygen consumption (and correspondingly the metabolic rate) both as an immediate effect $[26,27]$ and as a longitudinal effect [26]. Certain yoga voluntarily regulated breathing techniques offer an opportunity to study the effects of changes in the respiratory pattern on metabolism [28]. Voluntary regulation of breathing in yoga alters autonomic activity with an improvement in cardiovascular and psychological health [29]. Nose is the main channel for the entry of air to the respiratory system, but this also exerts a resistance to the airflow. This nasal airflow resistance consists of half to $2 / 3 \mathrm{rd}$ of total airway resistance [30]. Nasal resistance is defined as resistance offered to the air entry by the nasal cavity [31]. This resistance is rather important as it prevents catastrophic collapse of lung [32]. Nasal airway resistance accounts for more than $50 \%$ of total airway resistance [33].The nasal cavity has been modeled as 2 resistors in parallel [34,35]. The 3 components of nasal resistance are as follows: the nasal vestibule, nasal valve, and nasal cavum [33].Information regarding nasal resistance is essential for management of anatomic and physiologic diseases of the na $\urcorner$ sal airway. However, there are often inconsistencies between subjective nasal obstructive symptoms and the objective appearาance of the nasal cavity [36]. Due to this discrepancy, objective diagnostic tools for the assessment of nasal patency or resistance are needed [37].The upper airway resistance can be measured with the help of a rhino manometer and lower airway resistance can be measured with a spiro meter. Anterior active rhino manometer is the most frequently used method in clinical practice according to the International Standardization Committee of Rhinomanometry, ICSR [38, 39]. The word rhinomanometry means 'rhino' for nose and 'manometer' for measurement of pressure [40]. Spirometry is a safe, practical and reproducible maximum breathing test that can be used in primary care to objectively determine the ventilatory capacity of the lungs. As already emphasised earlier in this article, it is the 'gold standard' for detecting and quantifying airflow obstruction [41]. A spiro meter is a medical device that allows measurement of how much air is expelled and how quickly the lungs can be emptied, in a maximal expiration from full inflation [42]. The test is relatively quick to perform, well tolerated by most patients and the results are immediately available to clinician [43]. Sofar there has not been much studies done to check the efficiency of Hatha yogasanas on the airway resistances of tobacco smokers with allergic rhinitis. Hence Hatha yogasanas comprising of breathing exercises were taught to the recruited subjects in the study and effect of these asanas on the airway resistances of tobacco smokers with allergic rhinitis was studied.

\section{Materials and Methods}

This study was conducted at the Department of Otorhinolaryngology, St. John's national academy of health sciences, Bangalore. The study is a prospective non blinded study. 20 Tobacco smokers with Allergic rhinitis between the age group of 18-30, willing to practice yoga for a period of 90 days and with full compliance and reduce the number of cigarettes were recruited for the study. The Nasal resistance was measured at day 0 , that is before the start of practicing yoga and then after a period the 90 days. Written and informed consent was taken before the procedure. A thorough otorhinolaryngological examination of all subjects was done prior to the study. The subjects were taught Hatha yogasanas by a trained yoga tutor. The following are the list of specific asanas which were taught

a) Tadasana (mountain pose)

b) Ardhachakrasana(Half-Wheel Posture )

c) Ardhakatichakrasana (Lateral arc posture)

d) Bhujangasana ( Cobra Pose )

e) Vrksasana ( Tree Pose )

f) Veerabadrasana(Warrior Pose)

g) Gomukasana ( Cow Face Pose )

h) Ustrasana ( Camel Pose )

i) Dhanurasana ( Bow Pose)

j) Surya Namaskara

k) Nadi Shodhana Pranayama ( Alternate Nostril Breathing Technique )

l) Bhastrika Pranayama ( The Bellows Breathing )

m) Bhramari Pranayama ( Humming Bee Breathing Technique )

n) Kapalabhati ( Hyperventilating Practice)

o) Jalaneti 
The rhino manometer and spirometer was used to assess objectively the effect of Hatha yogasanas on the airway resistance. Regular calibration was ensured. The technique of the whole procedure was explained in full detail to all subjects. Series of trial recordings were performed with an intention that they were familiar with the technique and equipment thereby eliminating any anxiety which is a known factor for reducing nasal resistance. Rhinomanometry examination was performed during quiet breathing with close mouth in an upright sitting position and the following parameters were recorded [44].

Equipment used had following features:

1. During spontaneous respiration transnasal pressure differences and nasal air flow were recorded simultaneously.

2. Nasal air flow and pressure curve was displayed on a visual display unit (VDU) which allowed controlling the regularity of patients breathing.

3. Data obtained in the form of printed graph which contained nasal airflow and pressure-flow relation at $150 \mathrm{~mm}$ Pa pressure [30].

Nasal resistance was kept static at $150 \mathrm{~Pa}$ because at this pressure difference both laminar and turbulent airflow were prevailed and nasal resistance can be assessed with minimal physical effort. Calculations of transnasal resistance were made according to Ohm's law. Nasal resistance to airflow was calculated by following equation

$$
\mathrm{R}=\Delta \mathrm{P} / \mathrm{V}
$$

$\mathrm{R}$ is total nasal airflow resistance in $\mathrm{Pa} / \mathrm{cm}^{3} / \mathrm{s}$,

$\Delta \mathrm{P}$ is $150 \mathrm{~Pa}$ pressure, $\mathrm{V}$ is nasal airflow (sum of left and right) during inspiration.

Total nasal airflow resistance reflects the resistance of both side of nasal cavity. The advantage of measuring the total nasal airflow resistance is to avoid the effect of nasal

Cycle over unilateral nasal airflow resistance as the nasal cycle may lead to a change of 4-fold in unilateral nasal airflow resistance [45]. The subjective analysis was done using the SF12 Health survey questionnaire and SNOT questionnaire.

\section{Result}

The Objective analysis parameters pre yoga and post yoga was found to be as follows, Total Nasal Airway Resistance in the 20 subjects was $0.44 \mathrm{~Pa} / \mathrm{cm}^{3} / \mathrm{s}$ pre yoga and $0.39 \mathrm{~Pa} / \mathrm{cm}^{3} / \mathrm{s}$ post yoga at $150 \mathrm{~Pa}$ with $\mathrm{P}<0.05$. Pulmonary function test parameter FEV1/FVC\% pre yoga was 66.12 and 79.51 post yoga with $\mathrm{P}<0.001^{* * *}$. The subjective analysis parameters was found to be as follows, the Physical component score of the SF-12 health survey questionnaire was 38.62 pre yoga and 41.99 post yoga with $\mathrm{P}<0.05^{*}$ and Mental component score of the SF-12 health survey questionnaire was 40.04 pre yoga 45.07 post yoga with
$\mathrm{P}<0.01^{* *}$, and the SNOT questionnaire score was 12.77 pre yoga and 10.05 post yoga $\mathrm{P}<0.001^{* * *}$.

\section{Discussion}

Allergic Rhinitis (AR) is defined as inflammation of the membranes lining the nose, and is characterized by nasal congestion, rhino rhea, sneezing, itching of the nose and/or post-nasal discharge [46]. It is often viewed, as a trivial disease but can significantly affect the quality of life (QOL) by causing fatigue, headache, sleep disturbances and cognitive impairment [47] Allergic Rhinitis is also closely related to asthma and, 10$40 \%$ of people with rhinitis have concomitant asthma [47]. According to WHO (2007), the global burden of allergic rhinitis was estimated to be 400 million [48] and the prevalence among adults ranges between $10 \%$ and $32 \%$ in Asia Pacific region [49]. Despite the high burden, there is paucity of community based studies in India, determining the burden and factors associated with allergic rhinitis. Medications provide some relief, but improvement is only partial. Anti-IgE shots show better efficacy, but are still very expensive [50].

Tobacco smoke exposure remains common and has been linked with an increased risk of multiple upper respiratory conditions in various age groups. Significant associations have been suggested between tobacco smoke exposure and chronic sinusitis [51], asthma [52] and allergic rhinitis [53]. In developing countries such diseases pose a serious socio economic burden. Cost effective options and alternative therapy such as yoga will serve as a solution to manage Allergic rhinitis. Pranayama is an integral part of Hatha yogasanas. As a deep breathing technique, pranayama reduces dead space ventilation and decreases work of breathing. It also refreshes the air throughout the lungs, in contrast with shallow breathing that refreshes the air only at the base of the lungs [54]. Regular practice of pranayama improves cardiovascular and respiratory functions, improves autonomic tone toward the parasympathetic system, decreases the effect of stress and strain on the body and improves physical and mental health [55-57]. Pulmonary function parameters (PFT) provide important clinical information to identify and quantify the defects and abnormalities in the functioning of the respiratory system. A study by Dinesh etal ,after 12 weeks of fast pranayama training FEV1 /FVC, PEFR, and FEF25-75 were significantly improved $(\mathrm{P}=0.02, \mathrm{P}<0.001$, and $\mathrm{P}<0.001$, respectively) compared with the values at baseline. Yadav and Das attributed that improvement in the PFT parameters by yogic practices due to increased respiratory muscle strength, clearing of respiratory secretions and using the diaphragmatic and abdominal muscles for filling the respiratory apparatus more efficiently and completely. Furthermore, the improvement in the PFT parameters may be due to rise in thoracic - pulmonary compliances and broncho dilatation by training in Nadisodhana pranayamas [58]. Stimulation of pulmonary stretch receptors by inflation of the lung reflexely relaxes smooth muscles of larynx and tracheo bronchial tree. Probably, this modulates 
the airway caliber and reduces airway resistance [59]. Previous investigators demonstrated the effect of pranayama on enhancement of the respiratory muscle efficiency and lung compliance due to reduction in elastic and viscous resistance of lung [60]. Furthermore, pranayama acts as stimulus for release of lung surfactant and prostaglandins into alveolar spaces, which increases the lung compliances [61]. Total nasal resistance gives an overall measure of nasal functions and also reflects the degree of nasal obstruction during breathing [45].

Table 1: Comparison of Total Nasal Airway Resistance at $150 \mathrm{~Pa}$ pressure between Pre yoga and Post yoga in Tobacco smokers with Allergic Rhinitis $\mathrm{P}<0.05^{*}, \mathrm{P}<0.01^{* *}, \mathrm{P}<0.001^{* * *}$.

\begin{tabular}{|c|c|c|c|}
\hline $\begin{array}{c}\text { Total Nasal Airway Resistances } \\
\text { at Varied Pressures }\end{array}$ & Pre Yoga & $\begin{array}{c}\text { Post } \\
\text { Yoga }\end{array}$ & P Value \\
\hline Mean Resistance at $150 \mathrm{~Pa}$ & 0.44 & 0.39 & $<0.05^{*}$ \\
\hline
\end{tabular}

Table 2: Comparison of FEV1/FVC\% Pre yoga and Post yoga in Tobacco smokers with Allergic Rhinitis. $P<0.05^{*}, P<0.01^{* *}, P<0.001^{* * *}$

\begin{tabular}{|c|c|c|c|}
\hline $\begin{array}{c}\text { Spirometric } \\
\text { Value }\end{array}$ & Pre yoga & Post Yoga & P Value \\
\hline FEV1/FVC\% & 66.12 & 79.51 & $<0.001^{* * *}$ \\
\hline
\end{tabular}

Table 3: Comparison of Short Form 12- Health Survey questionnaire scores Pre yoga and Post yoga in Tobacco smokers with Allergic Rhinitis patients $\mathrm{P}<0.05^{*}, \mathrm{P}<0.01^{* *}, \mathrm{P}<0.001^{* * *}$.

\begin{tabular}{|c|c|c|c|}
\hline $\begin{array}{c}\text { Components of SF- } \\
\text { 12 Health Survey } \\
\text { Questionnaire }\end{array}$ & Pre Yoga & Post Yoga & P Value \\
\hline $\begin{array}{c}\text { Mean Physical Component } \\
\text { Score(PCS) of SF-12 Healthy } \\
\text { survey questionnaire }\end{array}$ & 38.62 & 41.99 & $<0.05^{*}$ \\
\hline $\begin{array}{c}\text { Mean Mental Component } \\
\text { Score(MCS) of SF-12 Health } \\
\text { survey questionnaire }\end{array}$ & 40.04 & 45.07 & $<0.01^{* *}$ \\
\hline
\end{tabular}

Table 4: Comparison of Sino Nasal Outcome Test (SNOT) Questionnaire scores Pre yoga and Post Yoga in Tobacco smokers with Allergic Rhinitis $\mathrm{P}<0.05^{\star}, \mathrm{P}<0.01^{* *}, \mathrm{P}<0.001^{* * *}$.

\begin{tabular}{|c|c|c|c|}
\hline SNOT Scores & Pre Yoga & Post Yoga & P Value \\
\hline $\begin{array}{c}\text { Mean SNOT } \\
\text { Scores }\end{array}$ & 12.77 & 10.05 & $0.001^{* * *}$ \\
\hline
\end{tabular}

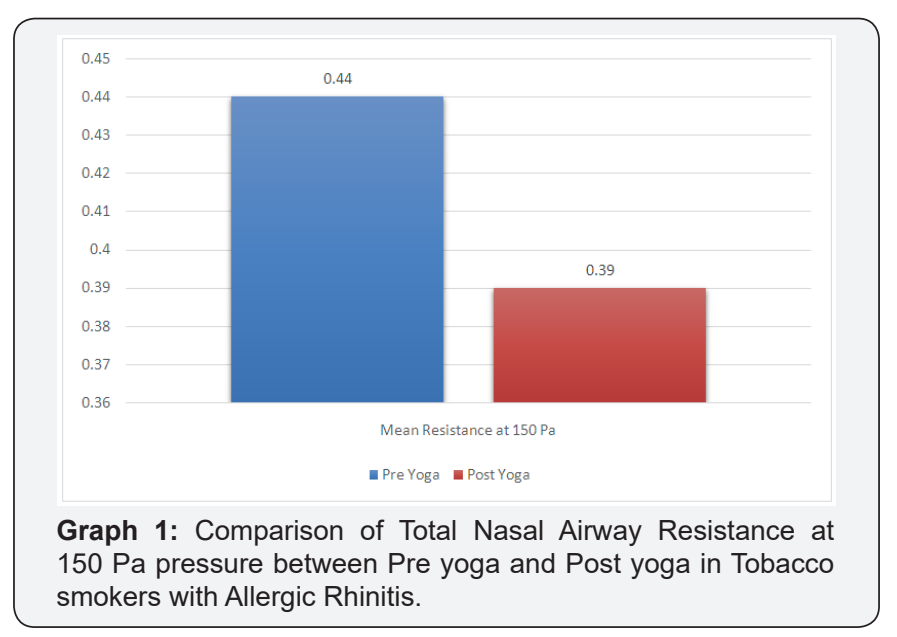

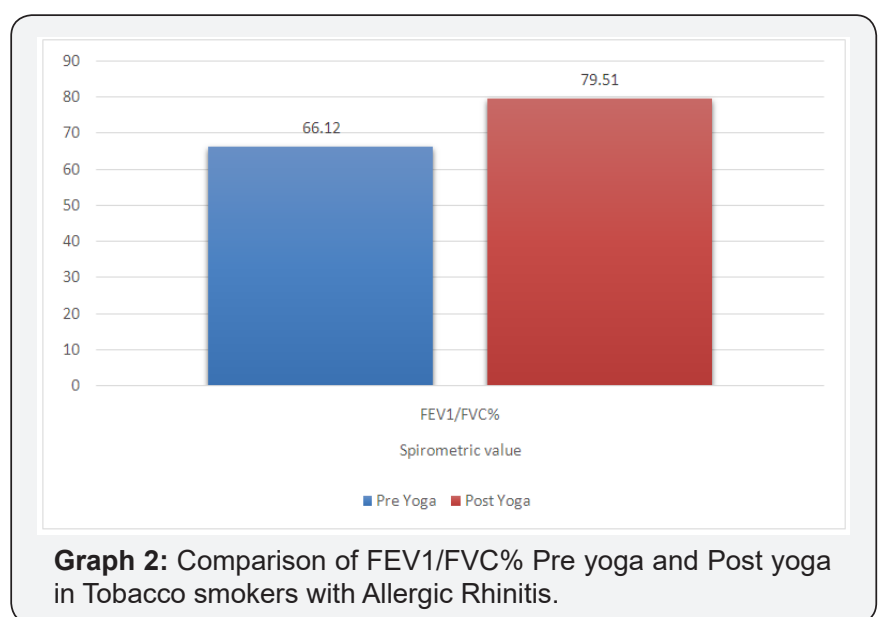

in Tobacco smokers with Allergic Rhinitis.
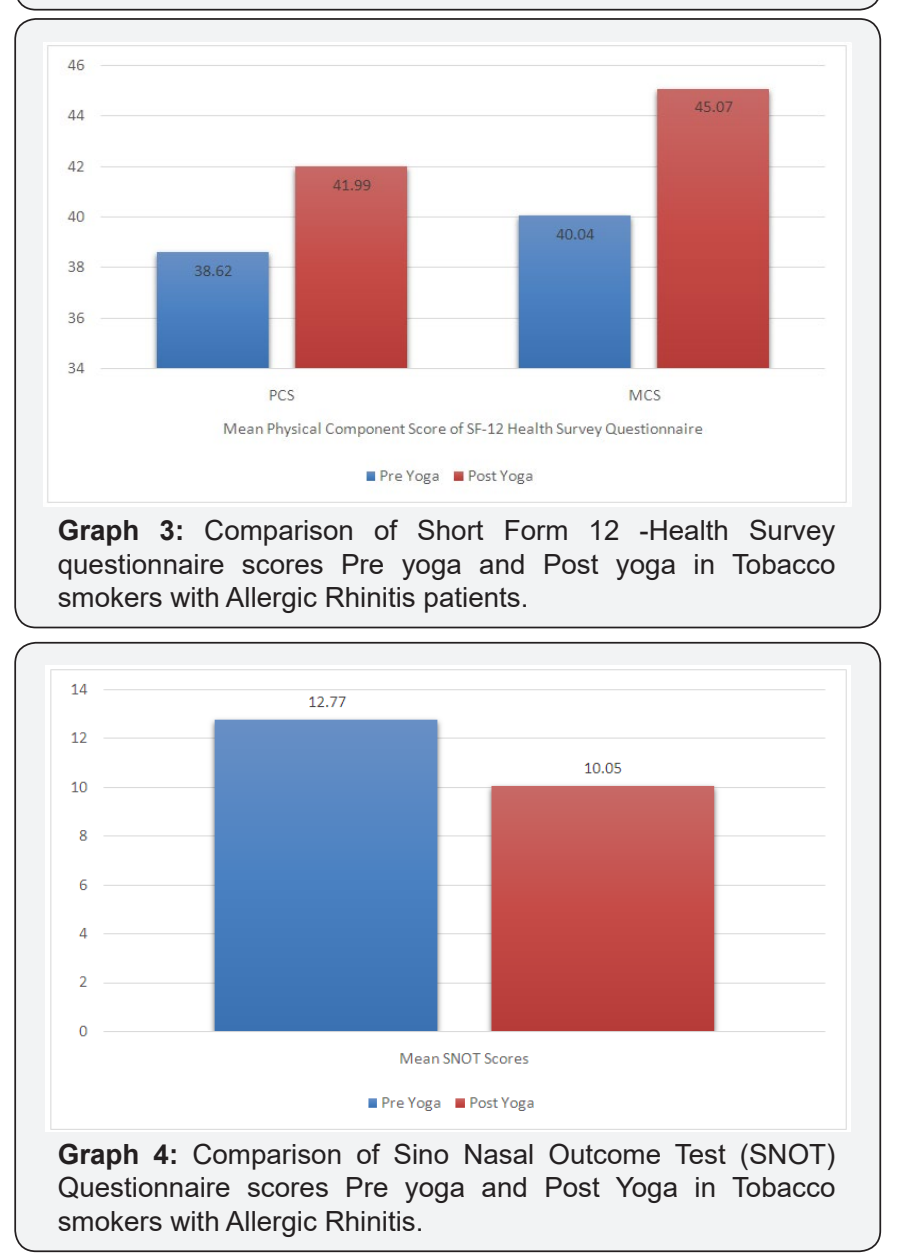

In our study Table 1 shows the Total Nasal Airway resistance in 20 subjects where in during preying it was 0.44 and post yoga it was 0.39 with the $p$ value $<0.05^{*}$. Graph 1 shows the decrease in total nasal airway resistance post yoga. Table 2 shows the Spiro metric measurements i.e, FEV1/FVC\% during pre yoga it was 66.12 and post yoga it was 79.51 with the $p$ value $<0.001^{* * *}$. Graph 2 shows the significant improvement of the FEV1/FVC\% parameter post yoga in the 20 subjects. Table 3 shows the SF12 Health survey components i.e the physical component score during pre yoga was 38.62 and post yoga was 41.99 with the $p$ value $<0.05^{*}$ and the mental component score during preying 
was 40.04 and post yoga was 45.07 with the $p$ value $<0.01^{* *}$. Graph 3 shows the significant improvement in the physical and mental component scores post yoga. Table 4 shows the SNOT scores which was 12.77 during pre yoga and 10.05 post yoga with the $\mathrm{p}$ value $0.001^{* * *}$. Graph 4 shows the significant reduction in the SNOT score post yoga.

\section{Conclusion}

The study shows that there is decrease in the total nasal airway resistance and the FEV1/FVC\% parameter also show significant improvement in 20 tobacco smokers with allergic rhinitis after the regular practice of yoga. The Quality of life of the subjects has been better as per the SNOT and SF 12 Questionnaire. There have been no scientific studies concerning the effect of yoga on the airway resistances of tobacco smokers with allergic rhinitis. Thus this study may form a basis for future studies focused on the effect of yoga on the tobacco smokers with allergic rhinitis.

\section{Acknowledgement}

The authors thank Indian council of medical research for funding the research study and St. John's national academy of health sciences, Bangalore for providing the infrastructure to carry out the study.

\section{References}

1. Khazaei HA, Khazaei B, Dashtizadeh GA, Mohammadi M (2015) Cigarette smoking and skin prick test in patients with allergic rhinitis. Int J High Risk Behav Addict 4(3): e23483.

2. Khazaei HA, Moulaei NA, Tabatabaei SNA, Khazaei A, Khosravi A (2014) The effect of smoke cigarette on immune responses of allergic rhinitis patients. Biosc Biotech Res Asia 11(2): 925-930.

3. Tsvetkova-Vicheva VM, Gecheva SP, Komsa-Penkova R, Velkova AS, Lukanov TH (2014) IL-17 producing $\mathrm{T}$ cells correlate with polysensitization but not with bronchial hyper responsiveness in patients with allergic rhinitis. Clin Transl Allergy 4(1): 3.

4. Wang Y, Chen S, Wang P, Tan C, Zhang C, et al. (2014) Comparison of clinical effectiveness of acupuncture and a Western drug on allergic rhinitis: study protocol for a randomized controlled trial. J Tradit Chin Med 34(3): 254-260.

5. Shariat M, Pourpak Z, Khalesi M, Kazemnejad A, Sharifi L, et al. (2012) Quality of life in the Iranian adults with allergic rhinitis. Iran J Allergy Asthma Immunol 11(4): 324-328.

6. Satish Nair (2012) Nasal breathing exercise and its effect on symptoms of allergic rhinitis. Indian J Otolaryngol Head Neck Surg 64(2): 172176.

7. Annesi JJ (2005) Changes in depressed mood associated with 10 weeks of moderate cardiovascular exercise in formerly sedentary adults. Psychol Rep 96: 855-862.

8. Dunn AL, Trivedi MH, O'Neal HA (2001) Physical activity doseresponse effects on outcomes of depression and anxiety. Med Sci Sports Exerc 33(6 Suppl): S587-597.

9. Matsouka O, Kabitsis C, Harahousou Y, Trigonis I (2005) Mood alterations following an indoor and outdoor exercise program in healthy elderly women. Percept Mot Skills 100: 707-715.

10. Scully D, Kremer J, Meade MM, Graham R, Dudgeon K (1998) Physical exercise and psychological well being: a critical review. Brit J Sports
Med 32(2): 111-120.

11. Mishra RS (1987) Fundamentals of Yoga: A Handbook of Theory, Practice and Applications. Harmony Books, New York, USA.

12. Daubenmier JJ (2005) The relationship of yoga, body awareness, and body responsiveness to self-objectification and disordered eating. Psychol Women 29: 207-219.

13. Janakiramaiah N, Gagadhar BN, NagaVenkatesha-Murthy PJ, Harish MG, Subbakrishna DK, et al. (2000) Antidepressant efficacy of Sudarshan Kriya Yoga (SKY) in melancholia: a randomized comparison with electroconvulsive therapy (ECT) and imipramine. J Affect Disord 57(1-3): 255-259.

14. Carlson LE, Culos-Reed N, Daroux LM (2005) The effects of therapeutic yoga on salivary cortisol, stress symptoms, quality of life and mood states in cancer outpatients: a randomized controlled study. Presented at the Annual Meeting of the American Psychosomatic Society, Vancouver, Canada.

15. Khumar SS, Kaur P, Kaur S (1993) Effectiveness of shavasana on depression among university students. Indian J Clin Psychol 20: 82-87.

16. Malathi A, Damodaran A, Shah N, Patil N, Maratha S (2000) Effect of yoga practices on subjective well being. Indian J Physiol Pharmacol 44(2): 202-206.

17. Woolery A, Myers H, Sternlieb B, Zeltzer L (2004) A yoga intervention for young adults with elevated symptoms of depression. Altern Ther Health Med 10(2): 60-63.

18. Ernst E (2000) Breathing techniques-adjunctive treatment modalities for asthma? Systematic review. Eur Respir J 15(5): 969-972.

19. Ram FSF, Holloway EA, Jones PW (2003) Breathing retraining for asthma. Resp Med 97(5): 501-557.

20. Silvia F, Claudia A, Alessandra C, Paulo C, Cassio I (2016) Prevalence of self-reported smoking experimentation in adolescents with asthma or allergic rhinitis. J Bras Pneumol 42(2): 84-87.

21. Gómez M, Vollmer WM, Caceres ME, Jossen R, Baena-Cagnani CE (2009) Adolescent smokers are at greater risk for current asthma and rhinitis. Int J Tuberc Lung Dis 13(8): 1023-1028.

22. Mak KK, Ho RC, Day JR (2012) The associations of asthma symptoms with active and passive smoking in Hong Kong adolescents. Respir Care 57(9): 1398-1404.

23. Yoo S, Kim HB, Lee SY, Kim BS, Kim JH, et al. (2009) Effect of active smoking on asthma symptoms, pulmonary function, and BHR in adolescents. Pediatr Pulmonol 44(10): 954-961.

24. Taimini IK (1961) The Science of Yoga. The Theosophical Publishing House; Madras, India.

25. Cavallera GM, Gatto M, Boari G (2014) Personality, cognitive styles and Morningness-Eveningness disposition in a sample of Yoga trainees. Med Sci Monit 20: 238-246.

26. Telles S, Nagarathna R, Nagendra HR (1996) Physiological measures during right nostril breathing. J Altern Complement Med 2(4): 479484.

27. Telles S, Nagarathna R, Nagendra HR (1994) Breathing through a particular nostril can alter metabolism and autonomic activities. Indian J Physiol Pharmacol 38(2): 133-137.

28. Telles S, Naveen KV (2008) Voluntary breath regulation in yoga: Its relevance and physiological effects. Biofeedback 36: 70-73.

29. Critchley HD, Nicotra A, Chiesa PA, Nagai Y, Gray MA, et al. (2015) Slow breathing and hypoxic challenge: cardiorespiratory consequences and their central neural substrates. PLoS One 10: e0127082.

30. Shailendra Gupta, Ankur Bansal, Sunil Ramnani, Sanjay Kumar, Goyal NK (2012) Assessment of Nasal Airflow Resistance in the Healthy 


\section{Journal of Yoga and Physiotherapy}

Population of Chattisgarh by Active Anterior Rhinomanometry. Indian J Otolaryngol Head Neck Surg. October-december 64(4): 338-340.

31. Butler J (1960) The work of breathing through the nose. Clin Sci 19: $55-62$.

32. Balasubramanian Thiagarajan (2012) Nasal resistance. Its importance and measurement. Rhinology.

33. Bailey B (1998) Nasal function and evaluation, nasal obstruction. In: Head and Neck Surgery: Otolaryngology ( $2^{\text {nd }}$ edn.), New York, USA.

34. Kerr A (1997) Rhinology. In: Scott-Brown's Otolaryngology ( $6^{\text {th }}$ edn.) Butterworth-Heinemann, Oxford, UK.

35. Cummings C (1999) Otolaryngology: head and neck surgery. St. Louis, Mo: Mosby Year-Book, Missouri, United States, pp. 801-806.

36. Kim CS, Moon BK, Jung DH, Min YG (1998) Correlation between nasal obstruction symptoms and objective parameters of acoustic rhinometry and rhinomanometry. Auris Nasus Larynx 25(1): 45-48.

37. Se Joong Kim, Ji Ho Choi, Eun Joong Kim, Seung Ku Lee, Seung Hoon Lee, et al. (2012) A Prospective population-based study of total nasal resistance in korean subjects. Clin Exp Otorhinolaryngol 5(1): 39-43.

38. Clement PA, Gordts F (2005) Consensus report on acoustic rhinometry and rhinomanometry. Rhinology 43(3): 169-179.

39. Clement PA (1984) Committee report on standardization of rhinomanometry. Rhinology 22(3): 151-155.

40. Eccles R (2011) A guide to practical aspects of measurement of human nasal airflow by rhinomanometry. Common cold centre and healthcare clinical trials, Cardiff school of Biosciences, Cardiff University, United Kingdom, pp. 49: 2-10.

41. Global Initiative for Chronic Obstructive Lung Disease (GOLD) Global Strategy for the Diagnosis, Management and Prevention of COPD 2013.

42. Hutchinson J (1846) On the capacity of the lungs, and on the respiratory functions, with a view of establishing a precise and easy method of detecting disease by the spirometer. Med Chir Trans 29: 137-252.

43. Enright PL, Beck KC, Sherrill DL (2004) Repeatability of Spirometry in 18,000 Adult Patients. Am J Respir Crit Care Med 169(2): 235-238.

44. Chellaa R, Soumya MS, Inbaraj G (2017) Indian J Otolaryngol Head Neck Surg.

45. Ohki M, Naito K, Cole P (1991) Dimensions and resistances of the human nose: racial differences. Laryngoscope 101(3):276-278.

46. (1994) International consensus report on the diagnosis and management of rhinitis. international rhinitis management working group. Allergy 49 (Suppl): 1-34.

47. Bousquet J, Khaltaev N, Cruz AA, Denburg J, Fokkens WJ, et al. (2008) Allergic Rhinitis and its Impact on Asthma (ARIA) 2008 update (in

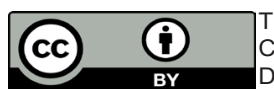

This work is licensed under Creative

Commons Attribution 4.0 License

DOI: 10.19080/JYP.2017.02.555594 collaboration with the World Health Organization, GA(2)LEN and AllerGen). Allergy 63(Suppl 86): 8-160.

48. (2007) World Health Organization. Global Surveillance, prevention and control of chronic Respiratory Diseases: A Comprehensive approach, Geneva, Swizerland.

49. Pawankar R, Baena-Cagnani CE, Bousquet J, Canonica GW, Cruz AA, et al. (2008) State of world allergy report 2008: Allergy and chronic respiratory diseases. World Allergy Organ J 1(Suppl): S4-S17.

50. Geoffroy solelhac, Denis charpin (2014) Management of allergic rhinitis: F1000 Prime Reports 6: 94.

51. Reh DD, Higgins TS, Smith TL (2012) Impact of tobacco smoke on chronic rhinosinusitis: a review of the literature. Int Forum Allergy Rhinol 2(5): 362-369.

52. Quinto KB, Kit BK, Lukacs SL, Akinbami LJ (2013) Environmental tobacco smoke exposure in children aged 3-19 years with and without asthma in the United States.

53. Saulyte J, Regueira C, Montes-Martinez A, Khudyakov P, Takkouche B (2014) Active or passive exposure to tobacco smoking and allergic rhinitis, allergic dermatitis, and food allergy in adults and children: a systematic review and meta-analysis. PLoS Med 11(3): e1001611.

54. Bijlani RL (2004) The yogic practices: Asanas, pranayams and kriyas In: Bijlani RL (Ed.), Understanding Medical Physiology. ( $3^{\text {rd }}$ ed), Jaypee Brothers Medical Publishers, India, pp. 883-889.

55. Udupa KN, Singh RH (1972) The scientific basis of yoga. JAMA 220(10): 1365.

56. Bhargava R, Gogate MG, Mascarenhas JF (1988) Autonomic responses to breath holding and its variations following pranayama. Indian J Physiol Pharmacol 32(4): 257-264.

57. Bal BS (2010) Effect of anulom vilom and bhastrika pranayama on the vital capacity and maximal ventilatory volume. J Physical Educ Sport Manage 1(1): 11-15.

58. Yadav RK, Das S (2001) Effect of yogic practice on pulmonary functions in young females. Indian J Physiol Pharmacol 45(4): 493-496.

59. Mandanmohan, Jatiya L, Udupa K, Bhavanani AB (2003) Effect of yoga training on handgrip, respiratory pressures and pulmonary function. Indian J Physiol Pharmacol 47(4): 387-392.

60. Srivastava RD, Jain N, Singhal A (2005) Influence of alternate nostril breathing on cardiorespiratory and autonomic functions in healthy young adults. Indian J Physiol Pharmacol 49(4): 475-483.

61. Joshi LN, Joshi VD, Gokhale LV (1992) Effect of short term 'Pranayam' practice on breathing rate and ventilatory functions of lung. Indian J Physiol Pharmacol 36(2): 105-108.

\section{Your next submission with Juniper Publishers} will reach you the below assets

- Quality Editorial service

- Swift Peer Review

- Reprints availability

- E-prints Service

- Manuscript Podcast for convenient understanding

- Global attainment for your research

- Manuscript accessibility in different formats

( Pdf, E-pub, Full Text, Audio)

- Unceasing customer service

Track the below URL for one-step submission https://juniperpublishers.com/online-submission.php 